\title{
Research Note \\ Field Performance and Wine Quality Modification in a Clone of Vitis vinifera cv. Dolcetto after GLRaV-3 Elimination
}

\author{
Franco Mannini, ${ }^{1 *}$ Alessandra Mollo, ${ }^{1}$ and Rino Credi $^{2}$
}

\begin{abstract}
Grapevine leafroll is one of the most widespread virus diseases of grapevine and Grapevine leafrollassociated virus 3 (GLRaV-3) is one of its major causal agents. The effect of GLRaV-3 elimination was studied under vineyard conditions for two years by comparing the virus-free and infected lines of the same clone of Vitis vinifera cv. Dolcetto, an important red wine cultivar grown in northwestern Italy. The results confirmed the advantages of using virus-free vines in terms of field performance (vigor, yield, leaf photosynthesis, and juice soluble solids), whereas the advantages in wine quality were less evident. Sensory analysis clarified that the wine from virus-free vines was slightly different from that of vines infected by GLRaV-3, but did not indicate a significant preference for one or the other.
\end{abstract}

Key words: GLRaV-3, virus elimination, photosynthesis, wine, sensory analysis

Grapevine leafroll, one of the most widespread virus diseases of grapevine, is induced by single or mixed infections of virus species belonging to the Ampelovirus and Closterovirus genus (family Closteroviridae). At present, Grapevine leafroll-associated virus 3 (GLRaV-3) is considered the most significant (Martelli 2009). According to the literature available on GLRaV-3, the virus reportedly has negative affects on grape juice soluble solids and other qualitative parameters, such as the amount of anthocyanins in red grapes, more so than on vegetative vigor and yield (Walter and Martelli 1996, Guidoni et al. 1997, Cabaleiro et al. 1999, Borgo and Angelini 2002, Mannini 2003, Komar et al. 2007, Lee and Martin 2009). In these trials, however, the assessment of enological quality was only limited to grapes, while studies of virusfree versus GLRaV-3 wine comparisons are very limited. The most significant trial to date was conducted with Vitis vinifera $\mathrm{cv}$. Nebbiolo, which is used in several renowned red wines of northwest Italy, including Barolo and Barbaresco. In this case, the effect of GLRaV-3 elimination from vines enhanced wine quality, as expressed by a higher ranking in tasting in two out of three vintages (Mannini et al. 1998). The wines from virus-free plants were mainly preferred for their higher intensity of color and richer body. Increases in alcohol content and color intensity are also reported for wines made with grapes from GLRaV-3-free vines of Vitis vinifera

${ }^{1}$ CNR, Istituto di Virologia Vegetale, UOS Grugliasco, Torino, Italy; and ${ }^{2}$ Dipartimento di Scienze e Tecnologie Agroambientali, Patologia Vegetale, Università di Bologna, Italy.

*Corresponding author (email: f.mannini@ivv.cnr.it; fax: +39 011 6708658)

Manuscript submitted Feb 2011, revised Aug 2011, accepted Sept 2011. Publication costs of this article defrayed in part by page fees.

Copyright $(\underset{2}{ } 2012$ by the American Society for Enology and Viticulture. All rights reserved.

doi: 10.5344/ajev.2011.11020 cv. Tempranillo (Rioja, northern Spain) when compared to wines made with grapes from infected plants (Legorburu et al. 2009). It is difficult, however, to generalize these results because each wine cultivar is characterized by grapes of different composition.

The present study focused on evaluating the effect of GLRaV-3 infection on the agronomic traits and fruit and wine composition of Vitis vinifera cv. Dolcetto, another important red wine cultivar of northwest Italy, but with very different enological qualities than Nebbiolo. Dolcetto, unlike Nebbiolo, provides wines brighter in color and softer in body, which typically do not need any aging.

\section{Materials and Methods}

Plant materials and field trial. A clone of Vitis vinifera cv. Dolcetto formerly infected by GLRaV-3 and tested free from Grapevine fanleaf virus (GFLV), Grapevine leafrollassociated virus 1 (GLRaV-1), Grapevine virus A (GVA), and Grapevine fleck virus (GFkV) was heat-treated and GLRaV-3 was eliminated (Guidoni et al. 1997). Buds collected from both infected and virus-free mother plants were propagated by grafting on healthy Kober 5BB rootstock. In 2000, a row of 80 infected vines was planted alongside a row of 80 virusfree vines. Both rows were vertically trained and single cane pruned and were set in the middle of a commercial vineyard in Mondovì (Piedmont region, northwestern Italy) in a typical area of Dolcetto cultivation. The plantation density was 5000 vines per hectare.

Multiplex RT-PCR and DAS-ELISA. In 2007, a repeated molecular diagnostic testing on the original virus-free and infected mother vines by multiplex RT-PCR (Gambino and Gribaudo 2006) confirmed their sanitary status. This assay also excluded the presence of Grapevine leafroll-associated virus 2 (GLRaV-2) and Grapevine virus B (GVB). The virological status in the vineyard was then serologically assessed 
over time by randomly testing 20 plants in each of the two rows, within the 30 chosen for agronomic evaluations and winemaking. DAS-ELISA assays were performed on dormant cane samples, using commercial kits (Agritest Srl, Valenzano, Bari, Italy) and according to the manufacturer's instructions.

Data collection. When the vineyard reached full production, the main agronomic parameters (yield, numbers of clusters, cluster weight, pruning wood weight) and juice composition were assessed for two years (2005 and 2007) on four replicates of six plants of each virological status. Along the rows, virus-free replicates faced GLRaV-3 infected replicates. In addition, they were chosen within the 30 vines in the middle of the rows with the exclusion of the vines at the beginning and at the end of the rows. The objective was to reduce the variability in the soil present along the row, which was minimal between the rows with only a distance of $2.5 \mathrm{~m}$ separating the facing treatment. The 2006 vintage was lost because of summer hail. The juice analytical parameters of the grapes (soluble solids, total acidity, $\mathrm{pH}$ ) were measured on the whole harvest of each of the four replicates of six plants for each virological status according to specified methods (OIV 2008). Tartaric acid and malic acid content were analyzed using an HPLC system (P100-AS3000, Thermo Electron Corporation, Waltham, MA) equipped with a Spectra Focus diode array detector (UV3000, Spectra Physics Analytical, San Jose, CA) set to $210 \mathrm{~nm}$.

In mid-August 2007, leaf photosynthetic activity, transpiration rate, and stomatal conductance were measured using a portable infrared gas analysis system (ADC LCA3; Analytical Development Company, Hoddeson, UK). Measurements were carried out on 12 leaves sampled between the eighth and tenth node from the shoot base of three infected and three virusfree adjacent vines. The plots of three vines, chosen within the same 24 vines used for agronomic evaluations, were facing each other and were replicated three times for a total of 36 leaves of each sanitary status. The system was equipped with a Parkinson leaf chamber (PLC; Analytical Development Company) that exposed $6.25 \mathrm{~cm}^{2}$ of leaf area. Environmental conditions during the photosynthetic measurements were stable: $\geq 1.7 \mu \mathrm{mol} \mathrm{m} \mathrm{m}^{-2} \mathrm{~s}^{-1}$ photosynthetic active radiation, $35 \%$ relative humidity, and $30^{\circ} \mathrm{C}$ chamber temperature. A sample of 50 leaves from each treatment was collected at the same date to measure the average square surface. The leaves were processed in laboratory with an LI-3000 leaf area meter (LICOR Biosciences, Bad Homburg, Germany).

Microvinification. In the 2005 and 2007 vintages, $\sim 40$ and $60 \mathrm{~kg}$ of grapes from both infected and virus-free vines, respectively, were collected for small-scale winemaking. Grapes were collected from the same vines used for agronomic evaluations and, to reach the suitable amount of grape, from a contiguous extra replicate of six vines.

Winemaking was conducted rigorously in the same way for both treatments: after grape crushing and destemming, musts were placed in $100 \mathrm{~L}$ fiberglass containers and potassium metabisulfite (6 g/100 kg grapes), fermentation activators, and active dry yeast (Saccharomyces cerevisiae) were added for a simultaneous start to the process. After nine days of maceration, the wines were drawn off, allowed to sediment for five days, and then set into $50 \mathrm{~L}$ glass containers, where the wines were inoculated with selected bacteria Oenococcus oeni (Viniflora Oenos, Chr. Hansen, Hørsholm, DK) to facilitate malolactic fermentation at a controlled temperature ( 22 to $24^{\circ} \mathrm{C}$ ). At the end of process, $\mathrm{SO}_{2}$ was brought to $\sim 30$ $\mathrm{mg} / \mathrm{L}$, and the wines were then decanted twice within 25 days and placed for 15 days at $-5^{\circ} \mathrm{C}$ for tartaric stabilization. Wine bottling was carried out six months after harvest.

Chemical and sensory analysis. Chemical and sensory evaluations were then performed on the wines after a few months of rest in a cellar. The main analytical parameters of wines (alcohol, dry extract, titratable acidity, $\mathrm{pH}$, tartaric acid, lactic acid, potassium, ash, total phenols, total anthocyanins, color intensity, color hue) were measured according to specified methods (OIV 2008). Sensory evaluations of wines were carried out by the duo-trio test (i.e., the panel must pick out the two identical wines among a group of three) and paired-preference test (Roessler et al. 1978). A characterization test was also applied on 2007 wines to investigate the intensity of the different components of color, bouquet, and taste (Guinard and Noble 1986, Cravero and Ubigli 2002).

Statistical analysis. Data collected were processed by ANOVA for statistical significance (SAS Institute, Cary, NC).

\section{Results and Discussion}

Vine vigor, expressed as winter pruning wood weight, and yield of healthy vines were higher than that of GLRaV-3 infected vines in both years under study, although differences were more evident in the 2007 vintage (Table 1). The superior production was due to larger bunches and higher fertility (expressed as number of clusters per vine at harvest). Despite the higher yield, the berry juice of virus-free plants was slightly higher in soluble solids concentration compared to that from the infected plants. In 2007 this result was associated with greater leaf physiological efficiency registered in mid-August and to a larger average leaf surface (183 vs. 158 $\mathrm{cm}^{2}$ ). The difference in net photosynthesis rate was higher for the healthy canopy than for the infected foliage ( 9.5 vs. 6.8 $\left.\mu \mathrm{mol} \mathrm{CO} \mathrm{Cm}^{-2} \mathrm{~s}^{-1} ; p \leq 0.01\right)$ as well as stomatal conductance

Table 1 Field performances and juice composition of virus-free and GLRaV-3-infected vines of the same clone of Vitis vinifera cv. Dolcetto, 2005 and 2007 vintages.

\begin{tabular}{|c|c|c|c|c|}
\hline \multirow[b]{2}{*}{ Variable } & \multicolumn{2}{|c|}{2005} & \multicolumn{2}{|c|}{2007} \\
\hline & Virus-free & GLRaV-3 & Virus-free & GLRaV-3 \\
\hline Yield (kg/vine) & $1.54^{* a}$ & $1.30^{*}$ & $2.46^{*}$ & $1.75^{\star}$ \\
\hline Bunch wt (g) & $226^{*}$ & $192^{*}$ & $230^{*}$ & $171^{*}$ \\
\hline Bunch/vine $(n)$ & 7.1 & 6.6 & $11^{*}$ & $10^{*}$ \\
\hline Pruning wood wt (g/vine) & $383^{*}$ & $238^{*}$ & $382^{*}$ & $247^{*}$ \\
\hline Soluble solids $(\mathrm{g} / \mathrm{L})$ & 250 & 235 & 205 & 195 \\
\hline $\begin{array}{l}\text { Titratable acidity } \\
\text { (g/L tartaric acid) }\end{array}$ & 5.88 & 5.50 & 7.50 & 7.59 \\
\hline $\mathrm{pH}$ & 3.14 & 3.18 & $3.11^{*}$ & $3.05^{*}$ \\
\hline Tartaric acid (g/L) & 6.15 & 5.66 & 5.92 & 7.05 \\
\hline Malic acid (g/L) & 0.89 & 0.80 & 2.09 & 2.12 \\
\hline
\end{tabular}

aMeans followed by * statistically differ at $p \leq 0.05$. 
(387 vs. $308 \mathrm{mmol} \mathrm{H}_{2} \mathrm{O} \mathrm{m}^{-2} \mathrm{~s}^{-1} ; p \leq 0.05$ ), while transpiration rate did not reach statistical significance ( 4.39 vs. $4.01 \mathrm{mmol}$ $\left.\mathrm{CO}_{2} \mathrm{~m}^{-2} \mathrm{~s}^{-1}\right)$. At mid-August, leafroll symptoms (i.e., leaf reddening and rolling) were clearly detectable only on the basal leaves of GLRaV-3 infected plants, therefore the decline in physiological activity was registered on still nonsymptomatic leaves (sampled between the eighth and tenth node). The reduction in the physiological efficiency then cannot simply be explained as a consequence of symptom appearance, but it is attributable to a more complex virus physiological effect.

The 2005 and 2007 growing seasons were climatically different. The former was warmer and dryer than 2007, especially during the ripening period, thereby favoring good grape maturation. In general, both 2005 wines were highly alcoholic and rich in color despite the different sanitary status of the vines of origin (Table 2). Because of the relative homogeneity of the wines, the duo-trio test performed on the 2005 products was not significant (only 9 correct responses out of 15) and for this reason the paired-preference test was not carried out.

In the more climatically limiting 2007 season, alcohol content was in general much lower than in 2005; by contrast, however, the wines showed more differences. Alcohol content by volume was higher in the wine obtained from the virus-free plants, while titratable acidity was lower and consequently the $\mathrm{pH}$ was higher. The total phenol content, however, was lower (as in the 2005 vintage) with some implications for wine color and body. Phenolic maturity does not always coincide with the maturity in terms of sugar accumulation. The lower phenol content registered in the wine of healthy plants (despite the higher alcohol) could be a consequence of the higher yield and particularly of the increase in the bunch size due to GLRaV-3 elimination, which could have slowed phenolic maturation.

Regarding sensorial evaluation of 2007 wines, a trained panel of 16 tasters correctly paired the same wines in the

Table 2 Composition of wines obtained in two vintages from virus-free and GLRaV-3-infected vines of the same clone of Vitis vinifera cv. Dolcetto.

\begin{tabular}{|c|c|c|c|c|}
\hline \multirow[b]{2}{*}{ Variable } & \multicolumn{2}{|c|}{2005} & \multicolumn{2}{|c|}{2007} \\
\hline & Virus-free & GLRaV-3 & Virus-free & GLRaV-3 \\
\hline Alcohol (\% vol) & 14.80 & 14.76 & 12.43 & 11.89 \\
\hline Dry extract (g/L) & 23.9 & 23.7 & 22.0 & 21.9 \\
\hline $\begin{array}{l}\text { Titratable acidity } \\
\text { (g/L tartaric acid) }\end{array}$ & 5.92 & 5.44 & 5.77 & 6.15 \\
\hline $\mathrm{pH}$ & 3.35 & 3.45 & 3.39 & 3.33 \\
\hline Tartaric acid (g/L) & 1.68 & 1.49 & 1.64 & 2.03 \\
\hline Lactic acid (g/L) & 1.11 & 0.45 & 1.63 & 1.56 \\
\hline Potassium (mg/L) & 637 & 808 & 750 & 703 \\
\hline Ash (g/L) & 1.86 & 2.02 & 2.01 & 1.90 \\
\hline $\begin{array}{l}\text { Total phenols } \\
\text { (mg/L +catechin) }\end{array}$ & 1800 & 2050 & 2130 & 2450 \\
\hline $\begin{array}{l}\text { Total anthocyanins } \\
\text { (mg/L malvidin) }\end{array}$ & 274 & 323 & 217 & 211 \\
\hline $\begin{array}{l}\text { Color intensity } \\
(A 420+520+620)\end{array}$ & 16.50 & 16.80 & 8.42 & 8.56 \\
\hline Color hue (A420/520) & 0.56 & 0.55 & 0.67 & 0.60 \\
\hline
\end{tabular}

duo-trio test (12 correct responses out of 16), thus confirming the two wines were fairly different. In this case, however, the preferences of tasters were shared fairly between both wines and therefore the paired-preference test had no significance (Figure 1).

The characterization test was much more useful to better understand the effective differences between the 2007 wines (Figure 2). According to the described sensory characteristics, the wine from healthy vines had significantly fewer intense violet nuances in color, a richer bouquet (fruity flavors), and a lighter body, which resulted in a lower astringency and higher softness. In other words, the wine obtained from the virus-free plants was slightly more "ready to drink" than the wines from GLRaV-3-infected plants. On the contrary, the wines from the diseased plants showed brighter violet nuances in color (probably due to lower $\mathrm{pH}$ ) and a richer body with a consequent stronger astringency in taste. These findings are in contrast with the results reported on Nebbiolo and Tempranillo, where the wines from GLRaV-3 free plants showed an increase in color intensity (Mannini et al. 1998, Legorburu et al. 2009). For Nebbiolo, a possible explanation could be found in the different anthocyanins profile of the two

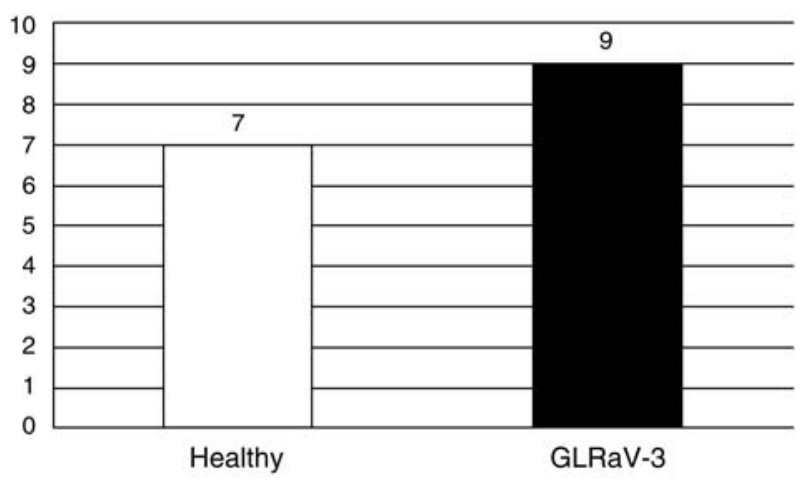

Figure 1 Paired-preference test on 2007 wines obtained from virusfree and GLRaV-3-infected vines of the same clone of Vitis vinifera cv. Dolcetto.

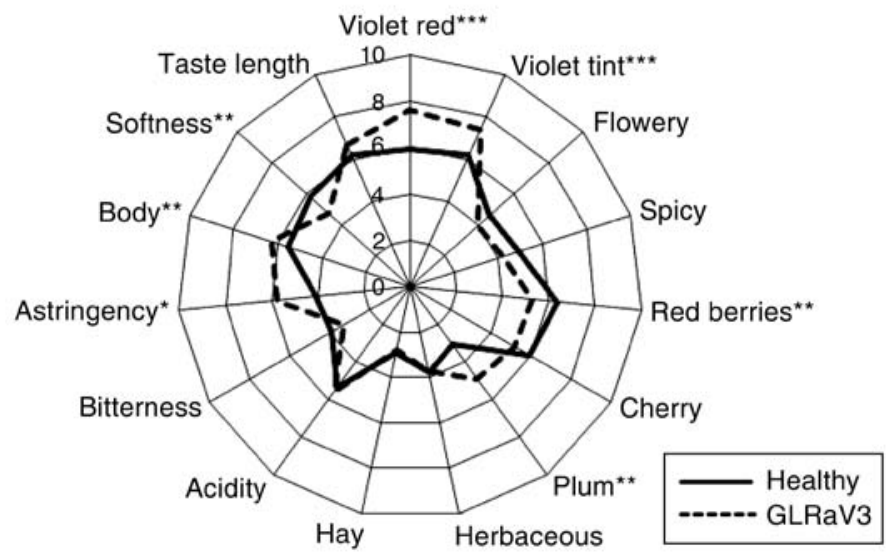

Figure 2 Characterization test on 2007 wines from virus-free and GLRaV-3-infected vines of the same clone of Vitis vinifera cv. Dolcetto $\left({ }^{*}\right.$, ${ }^{* *}$, and ${ }^{* * *}$ indicate significant differences at $p \leq 0,05,0,01$, and 0.001 , respectively). 
cultivars. In Dolcetto grapes, malvidin-3-glucoside (the most determinant anthocyanin for the intensity and the stability of wine color) is prevalent, while peonidin-3-glucoside, which rapidly undergoes enzymatic degradation at the end of fermentation, prevails in Nebbiolo. That is why color intensity and hue are usually a critical point for Nebbiolo wines, which are therefore much more susceptible then Dolcetto wines to modification in malvidin content. In Tempranillo, grown in the cool climate of northern Spain, the overall delay in grape maturity due to GLRaV-3 could have also penalized accumulation of anthocyanins in the berry skin.

\section{Conclusion}

The elimination of GLRaV-3 from a clone of Vitis vinifera cv. Dolcetto resulted in an overall improvement of field performances (higher vigor, yield, number and size of bunches, soluble solids, and leaf photosynthetic activity). However, it did not result in a tangible improvement of wine quality as expected by previous experience with other cultivars. The wines obtained from both virus-free and infected plants were similar in 2005 and slightly different in 2007. With the 2007 wine, however, tasters were unable to award their preferences to either wine. The wine from the healthy plants although more alcoholic, richer in flavor and smoother in taste, was slightly lighter in color and body, as confirmed by the lower total phenol content registered by chemical analysis. These characteristics, appreciable when the wine is consumed young as in the case of Dolcetto wines, could be a weakness for wines kept for longer in the cellar or on a market shelf.

The results of the trial confirm the advantages of using healthy vines in terms of field performance; however, at least under our experimental conditions, the advantages were less evident in terms of enological quality. The complexity of factors influencing the final wine quality, such as vintage, grape cultivar, environmental conditions, and training systems, makes the understanding of the virus infection/wine quality interaction complex and thereby it requires further investigation.

\section{Literature Cited}

Borgo, M., and E. Angelini. 2002. Influence of grapevine leafroll (GLRaV-3) on Merlot cv. grape production. Bull. OIV 75:611-622.

Cabaleiro, C., A. Segura, and J.J. García-Berrios. 1999. Effects of grapevine leafroll-associated virus 3 on the physiology and must of Vitis vinifera L. cv. Albariño following contamination in the field. Am. J. Enol. Vitic. 50:40-44.
Cravero, M.C., and M. Ubigli. 2002. Metodi di valutazione sensoriale per la caratterizzazione varietale dei vini rossi. Indus. Bevande 31:342-349.

Gambino, G., and I. Gribaudo. 2006. Simultaneous detection of nine grapevine virus by multiplex reverse transcription-polymerase chain reaction with coamplification of a plant RNA as internal control. Phytopathology 96:1223-1229.

Guidoni, S., F. Mannini, A. Ferrandino, N. Argamante, and R. Di Stefano. 1997. The effect of grapevine leafroll and rugose wood sanitation on agronomic performance and berry and leaf phenolic content of a Nebbiolo clone (Vitis vinifera L.). Am. J. Enol. Vitic. 48:438-442.

Guinard, J.X., and A. Noble. 1986. Proposition d'une terminologie pour une description analytique de l'arôme des vins. Sci. Alim. 6:657-662.

Komar, V., E. Vigne, G. Demangeat, and M. Fuchs. 2007. Beneficial effect of selective virus elimination on the performance of Vitis vinifera cv. Chardonnay. Am. J. Enol. Vitic. 58:202-210.

Lee, J., and R.R. Martin. 2009. Influence of grapevine leafroll associated viruses (GLRaV-2 and -3) on the fruit composition of Oregon Vitis vinifera L. cv. Pinot noir: Phenolics. Food Chem. 112:889-96.

Legorburu, F.J., E. Recio, E. López, J. Baigorri, M. Larreina, A. Remesal, J.F. Cibriaín, L. Caminero, J. Suberviola, and F. Aguirrezábal. 2009. Effect of Grapevine fanleaf virus (GFLV) and Grapevine leafroll-associated virus 3 (GLRaV-3) on red wine quality. In Extended Abstracts. 16 $6^{\text {th }}$ Meeting of the International Council for the Study of Virus and Virus-Like Disease of the Grapevine, Dijon, France, p. 251 (www.icvg.ch/archive.htm).

Mannini, F. 2003. Virus elimination in grapevine and crop performance. In Extended Abstracts. 14 $4^{\text {th }}$ Meeting of the International Council for the Study of Virus and Virus-Like Disease of the Grapevine, Locorotondo, Italy, pp. 234-239 (www.icvg.ch/archive.htm).

Mannini, F., V. Gerbi, and R. Credi. 1998. Heat-treated vs. virusinfected grapevine clones: Agronomical and enological modifications. Acta Hort. 473:155-163.

Martelli, G.P. 2009. Grapevine virology highlight 2006-2009. In Extended Abstracts. $16^{\text {th }}$ Meeting of the International Council for the Study of Virus and Virus-Like Disease of the Grapevine, Dijon, France, pp. 15-23 (www.icvg.ch/archive.htm).

OIV. 2008. Recueil international des méthodes d'analyse des vins et des moûts. Organisation Internationale de la Vigne et du Vin, Paris.

Roessler, E.B., R.M. Pangborn, J.L. Sidel, and H. Stone. 1978. Expanded statistical tables for estimating significance in paired-preference, paired-difference, duo-trio and triangle tests. J. Food Sci. 43:940-944.

Walter, B., and G.P. Martelli. 1996. Sélection sanitaire et sélection pomologique. Influences des viroses et qualité: Effet des viroses sur la culture de la vigne et ses produits. Bull. OIV 70:5-23. 